\title{
KNOWLEDGE ECONOMY, GLOBALIZATION AND TAXATION: WHAT CAN THE STATE DO?
}

\author{
Antonio Russo $^{1 *}$ \\ ${ }^{1}$ Author affiliation: Department of Political Sciences, University of Naples Federico II, Napoli, Italy \\ * Correspondent author: Antonio Russo - antonio.russo10@unina.it
}

Received: 8.3. 2021; Accepted: 13.4. 2021; Published: 17.5. 2021

Doi: https://doi.org/10.46473/WCSAJ27240606/17-05-2021-0003

Category: Research paper

\begin{abstract}
The article analyses the State's fiscal crisis and the impact on social inequalities in the global age. The old instruments of fiscal and monetary policy have lost much of their effectiveness, and they no longer allow capitalism to be governed at its present stage of development. The changes in the productive forces, modifying profoundly the economic structure, vary over time the effectiveness and the practicability of the macroeconomic regulation tools available for governments. The article sustains that is necessary to circumscribe the level of deep integration achieved by current economies to restore the redistributive action in modern democracies and to safeguard welfare systems, in order to face the effects of the technological restructuring underway. Globalisation, financialisation, and technological change are inextricably interconnected in cognitive capitalism and therefore require a unitary policy action to be adequately addressed by governments.
\end{abstract}

Keywords: Globalization; taxation; financialization; macroeconomic regulation.

\section{Introduction}

This article analyses the impact of the knowledge-based economy and globalization on the State's fiscal crisis, and the related impact on social inequalities. According to the hypothesis underlying this contribution, the increased social in inequalities - observed in all advanced countries in recent decades (Piketty, 2020) - is related to the ongoing technological revolution. This revolution is reshaping all economic sectors, from industry to services, with unprecedented speed and intensity (Baldwin, 2019; Brynjolfsson and Mcafee, 2017). These dynamics, inevitably, affects the functional distribution of income, inducing a tendential concentration of capital within an increasingly narrow core of owners of technologies and knowledge that give them a high monopoly power (Russo, 2019a). Redistributive policies, although they may affect these trends, cannot in any case reverse the structural trend towards the concentration of wealth, 
spontaneously generated by productive forces capable of replacing work in every sector and favouring the rapid rise of global big players, configuring monopolistic markets.

What can the State do to deal with this situation? In the academic and public debate, the need to strengthen or rediscover the welfare state role is frequently emphasised. Although this would have positive redistributive effects, the trajectory undertaken by the productive forces of cognitive capitalism, however, seems to circumscribe the effective practicability of this solution, and directly threaten the very sustainability of welfare systems at least on two different fronts (Russo, 2020):

by reducing taxable income, the fiscal crisis of the State worsens. The global mobility acquired by capital, and the stagnation of wages restrict the tax base and, with it, the tax revenues. Tax revenues are further contracted by the fall in taxation on businesses and the wealthiest taxpayers (Streeck, 2013; Crouch, 2011). Finally, the stagnation of the real economy itself exacerbates the fiscal crisis of the State:

- by reducing taxable income, the fiscal crisis of the State worsens. The global mobility acquired by capital, and the stagnation of wages restrict the tax base and, with it, the tax revenues. Tax revenues are further contracted by the fall in taxation on businesses and the wealthiest taxpayers (Streeck, 2013; Crouch, 2011). Finally, the stagnation of the real economy itself exacerbates the fiscal crisis of the State;

- by reducing the demand for work, new technologies determine a collateral increase in expenses for compensatory social policies measures. The growth of structural unemployment, in all advanced countries, raises the costs for the services provided, in the face of increasingly scarce resources.

The two main problems that have gripped capitalism from its origins, namely the inequality in the distribution of income and the rapid fluctuations in the unemployment rate, also characterize contemporary capitalism, despite the fact that the economy continues to grow and technological innovation advances. Such trends could induce a progressive concentration of wealth within an increasingly narrow core of market agents, against the backdrop of rapidly expanding poverty.

\section{The State's fiscal crisis}

The governments of advanced countries, with the crisis of the Keynesian paradigm and the decline of Fordist capitalism, have reacted to the economic difficulties (low growth, high unemployment, increased capital / labour conflict) using three different strategies (inflation, increase in public debt and private sector), to limit the declining trend in aggregate demand and the worsening of the distribution conflict (Streeck, 2013).

Through these expedients, non-existent or not yet available resources were surreptitiously introduced in advanced economies, inducing significant macroeconomic distortions, which subsequently required heavy rebalancing measures. More precisely:

- after the first strikes' wave, at the end of the 1960s, Western governments leveraged an inflationary monetary policy to boost further employment rate (Streeck, 2013). Stagflation, and the drastic disinflationary policies that followed, increased structural unemployment in all advanced economies. Since then, Western countries have faced high levels of unemployment. During the 1980s, monetary policy has been firmly anchored to the containment of inflation and no longer aimed at supporting full employment (Stiglitz, 2002), an objective that is instead considered a priority in Fordist 
capitalism. When the unemployment rate exceeds the critical threshold of $6 \%$, social inequality spontaneously tends to increase (Stiglitz, 2016). These changes in economic policy approach has had obvious effects on the functional distribution of income. A monetary policy geared to contain inflation weakens the position of workers and increases the benefits for capitalists;

- after the failure of the first strategy just discussed (based on an inflationary monetary policy), in many advanced economies governments leveraged the expansion of public spending and the growth of public debt to support aggregate demand (weakened by stagnant wages and unemployment). Already in the early 1990s, however, plans to reduce public debt were implemented, with cuts in social spending and the welfare state. In many cases, the increase in public debt was caused by tax cuts, and not by an out-ofcontrol social or welfare-state spending. Thus, in the United States, where the public debt rapidly increased, this trend is entirely attributable to the cut made on higher tax rates, in line with the policy suggestions of trickle-down economics (Russo, 2019b). The expected increase in revenue did not occur, and the economic policy measures implemented did not generate significant effects on economic growth, nor any real trickle-down effect. While the tax cuts have benefited wealthier taxpayers asymmetrically, the resulting spending cuts have weighed on the lower-middle classes, decreeing a general downsizing of public services;

- in the mid-1990s the third strategy was implemented. The weakness of aggregate demand, induced by public debt repayment plans, was addressed by launching a vast liberalisation program of the financial markets. Parallelly, it occurred rapid increase in private debt, facilitated by the cut in interest rates implemented in the same period. Since 1973 , the amount of debt in the US economy has doubled, reaching $300 \%$ of GDP (Mason, 2015). Meanwhile, the share of GDP produced by finance, the insurance sector and the real estate sector has risen from 15 to $24 \%$ and is now greater than that of industry (Mason, 2015). Similar trends were recorded in all advanced economies (Gallino, 2011). Financialization has allowed, at least for a certain phase, to offset any slowdown in the economy with a collateral expansion of credit. Thus, private debt was added to State debt. This dynamic was defined by Colin Crouch "privatized Keynesianism" (Crouch, 2009). The loss of net well-being for citizens, with steady wages for decades, and welfare services weakened by cuts to public spending, was compensated (temporarily and only apparently) by access to credit. However, the "gimmick" of financialization drastically ended in 2008 with the collapse of the world stock markets. To avoid the collapse of the global financial system, States have had to shoulder the huge losses of the banks and financial institutions in crisis, by launching extensive bailout programs. Consequently, the public debt of the advanced countries in the last decade has registered a further and considerable leap forward.

Thus, these three methods, adopted in last decades to create illusions of growth leveraging the money - inflation, public debt and private debt -worked just for a limited period of time (Streeck, 2013: 65). However, these three strategies have not eliminated the huge structural distortions that characterise current capitalism; they haven't given significant and stable stimulus to economic growth. So, these strategies have not provided any valid alternative to Keynesian policies to stabilise effective demand (Russo, 2017). Within an integrated global 
economy, the old instruments of fiscal and monetary policy have lost much of their effectiveness. Changes, occurred in the productive forces, modifying profoundly the economic structure, vary over time the effectiveness and the practicability of the macroeconomic regulation tools available for governments.

Today, advanced economies face a stagnation framework, combined with high unemployment, high public debt, and high private debt. For decades, advanced States has failed to give a lasting push to economic growth: a temporary growth increase has been achieved at the cost of unsustainable distortions in the medium term, generating frequent crises. Within this framework, «the functional tools for creating further growth illusions seem exhausted» [...] in the absence of new economic miracles, the capitalism of the future will have to get by without relying on the formula of peace typical of consumerism financed with the debt» (Streeck, 2013: 66-67).

After the end of Fordist capitalism, the relations of production present relevant difficulties in adapting to the new stage of development of the productive forces, and thus generate growing contradictions within the current model of cognitive capitalism. If in the Fordist capitalism a certain symbiosis between technological innovation and the well-being of the workforce seemed to have been triggered, in cognitive capitalism this link has been broken.

Each advancement of the productive forces, each evolution of the same, does not determine the simple repetition of the previous dynamics, but configures completely new conditions, placing the economic structure on a different stage in its historical development process. Consequently, the relations that are established between the economic sphere and state regulation also irreversibly change. The institutional arrangements, regulations, and policies so far could prove to be completely unsuitable for resolving the tensions within the emerging model of cognitive capitalism, and contradictions that the ongoing technological revolution will generate in the coming years. The relations of production, although they can be modified to mitigate the socially more disruptive effects of these transformations, cannot in any case reverse the structural trends triggered by the current productive forces, which make human labour substantially superfluous and the knowledge of vast segments obsolete (Baldwin, 2019; Russo, 2019a). As Marx foretold, «at a certain stage of their development the material productive forces of society enter into contradiction with the existing relations of production [...] A social formation never disappears until all the productive forces it is capable of creating have developed, just as one never arrives at new and more evolved relations of production before that their material conditions of existence have opened up in the very womb of the old society» (Marx, 2011: 547-548).

\section{The crisis of democracy in the era of cognitive capitalism}

The current Industrial Revolution is generating three fundamental consequences, essentially in line with Marxian forecasts relating to the effects unfolded by technological innovation:

structural decline in labour demand - while this is contracting, the labour market is changed by reforms aimed at making it more flexible. At the same time, the value of the labour force, in advanced countries, is devalued to face the growing global mobility of capital. This dynamic also increases the speed of extraction of surplus value from the living labour of the workers (Baldwin, 2019; Brynjolfsson and Mcafee, 2017);

- increase of social inequalities - redistributive policies are increasingly less able to counterbalance the current trend in inequalities growth, while the fiscal crisis of the State contributes to the progressive deconstruction of the welfare systems; 
- rise of multinational high-tech giants and decline of competition - the growing barriers to entry, in markets, lead to an increasingly oligopolistic-monopolistic configuration of the markets. Competition is declining, and also the rate of creation of new companies appears to be in sharp decline (Diez et al., 2018). As a result, the concentration of capital has increased, while wages are rather stagnant in the face of rapidly growing productivity. Given the high global mobility of capital, this favours the location in countries where multinational companies benefit of subsidised tax treatments.

Therefore, new technologies, devaluing jobs and making it more excessive with respect to the needs of capital enhancement, generate a spontaneous increase in social inequalities (Baldwin, 2019; Russo, 2019). At the same time, they sharpen the mobility of capital and make it less and less controllable (and taxable) by the State. Within this scenario, the capability of the State to implement effective redistributive actions is drastically reduced. In add to that, social tensions - generated by the cognitive capitalism - make unstable economic growth. So, the fundamental causes of these trends can be traced back to the trajectories undertaken by the productive forces, and only to a limited extent attributable to production relations; consequently, possibility for reformist action seem to be drastically reduced, unless acting on the current level of openness of the economies (Rodrik, 2015).

The growth of economic inequalities also tends to project itself on the political level, articulating artificial rents of position, instrumentally used to acquire even greater advantages on the economic level, inducing dangerous distortions in democratic practices (Crouch, 2014). The hegemony, exercised over the political sphere by those who already hold strong economic power, can lead to an even faster growth of economic inequalities.

The productive forces are not only actively reconfiguring the morphology of the capitalist structure, but there is a real risk that they could induce disruptive effects on the social contract that supports the functioning of modern democracies. Where the institutional structure and the regulatory framework of the market are defined according to the interests of the elite, they are irremediably averse to economic growth and democracy (Acemoglu and Robinson, 2012). Thus, when economic inequalities are translated into political inequalities, the rules of free competition are distorted, transforming inclusive institutions into institutions with extractive features (Acemoglu and Robinson, 2012). This shift makes the economic system stagnant, paralysed by positions' rents and barriers to the entry of markets articulated by distribution coalitions (Olson, 1982). The large concentrations of wealth constitute a huge obstacle both to the process of creative destruction (Schumpeter, 1943), on which the vitality of capitalist systems is based on, and to the proper functioning of democracies. When economic growth slows down, distribution conflicts inevitably tend to increase.

Therefore, in the future advanced democracies risk to be increasingly destabilised by the impossibility of solving problems generated by the transformations of capitalism, which they do not have the effective capacity to face. What can governments do to avert this scenario?

\section{The State and technological innovation}

As demonstrated by Mariana Mazzucato (2014), the State has historically played a central role in promoting radical technological innovations and basic research in pioneering sectors (biotechnology, nanotechnology, nuclear, space exploration) that do not generate immediate profits, and in which private companies therefore have no incentive to invest.

Carlota Pérez, in line with the Schumpeterian tradition, identifies the engine of economic growth in technological innovation. By merging Schumpeter with Keynes, Perez suggests to 
governments to support substantial investments in the IT and biotechnology sector to support the launch of sixth Koundratieff wave, within the 2020s of this century (Pérez, 2002). According to Pérez, however, technologies are not enough to launch a new technological wave: decisive support from the State is also needed.

In fact, also in global age governments continue to play an irreplaceable driving role in innovation, which also benefit private companies, in all key sectors of the knowledge economy:

- US pharmaceutical companies benefit greatly from significant investments (over 30 billion dollars per year) made by federal research centres (Mazzucato, 2014: 39). At the same time, the pharmaceutical giants have reduced internal investments for the development of new drugs, preferring to use the profits to support their respective stocks prices through the repurchase of stocks, or for speculative investments with immediate high profits (Mazzucato, 2014);

- the algorithm underlying the Google search engine was financed with funds from the US National Science Foundation, which did not obtain any economic return, despite having made a decisive contribution to the success of that start-up, which over the years has become a high-tech world giant;

- the main technologies incorporated in Apple's iPhones and iPads (from multitouch screens to GPS, from LCD technology to SIRI voice assistant) have been developed as part of research programmes financed by the US federal government (Mazzucato, 2014: 155), while the Cupertino's company invests just $2.6 \%$ of its profits in $R \& D$ activities, pays very little in taxes, and subcontracts production to Asian suppliers.

The myth of Silicon Valley as the fruit of entrepreneurial genius combined with free market is just that: a myth (Lerner, 2009), a partial history that hides the gigantic investments made by the US government in the area, especially in support of military research, and the related powerful spill over effects induced on the trajectories of the regional economy. As Joshua Lerner also points out, «every sector of advanced entrepreneurial activity in today's world has its origins in forceful government intervention» (Lerner, 2009: 42).

The problem is that large corporations, paying low taxes (due to both the reduction in taxation on capital and tax avoidance), do not participate in the investments in innovation from which they benefit, and they do not allow the State to have an indirect return from them, essential to make the huge expenditure in the sector sustainable. The contraction in tax revenues reduces the resources available to finance additional research programs in education, essential to support long-term growth. It is precisely these investments that shape, or regenerate, human capital, the most strategic resources for competition within a knowledge-based economy. The ability of leading companies to avoid taxation reduced positive externalities generated by their localization within national economies: «Decades of public investment in the scientific and technological base have made the United States a great country, but paradoxically it has failed to guarantee high levels of employment, increase tax revenues and promote the export of goods and services» (Mazzucato, 2014: 257).

The redefinition of taxation systems, in advanced countries, would allow the State to better capture the externalities generated by its investments in innovation, to obtain a more symmetrical distribution at social level of the benefits of innovation, currently strongly unbalanced to the advantage of leading companies. Most of the big high-tech players contribute only marginally to general wealth through taxation, financing collective goods for competitiveness provided by the State. They act as free riders, thanks to the high mobility and freedom of movement acquired by capital on a global scale. This structure of relations between 
the State and the market is clearly inefficient, and unsustainable in the long term. To save capitalism from the self-destructive dynamics, it is necessary strengthen the redistributive action of the State, and make it effective again.

\section{The taxation in global age}

As an OECD report points out, from the mid-nineties to 2005 , the reduced redistributive capacity of tax systems was the main source of the widening of the gap in family income (OECD, 2011: 18). A greater progressiveness of the tax system on the one hand, and a stricter antitrust regulation on the other, constitute the fundamental levers on which act reduce social inequalities. The OECD countries in which inequalities have grown the fastest in last decades are those in which the taxes paid by the highest incomes have registered the greatest cuts (Piketty et al. 2011). Robust empirical evidence, accumulated over the past decades through numerous comparative researches, demonstrates that «no advanced economy has achieved a low level of inequality and/or poverty [...] with a low level of social spending [...] Conversely, countries with relatively high social spending tend to present lower levels of inequality and poverty» (Marx et al., 2014: 18).

Lobbying activity, and the threat represented by the mobility of capital, have re-oriented fiscal policy on a favourable direction for capital (Hacker and Pierson, 2011). Acting simultaneously on the economic dimension and on the political sphere, the power gaps between top-incomes and lowest become self-reinforcing and tend to crystallise, with negative effects on the functioning of the democratic systems themselves (Crouch, 2014).

Critics of progressive taxation argue that technical progress and globalisation have contributed to lowering the Laffer curve and shifting its maximum to the left. Consequently, with the same tax burden, today the State would derive less revenue than in the Fordist era. But is it really so? Or, rather, is the idea that the State, in the current scenario cannot do much is it an unfounded justification for pushing the State to do less and less?

Taxing the highest incomes and leading companies, in the presence of high inequalities, would be a first and indispensable step to limit the further expansion of inequalities and the related threats, both political and economic, of a consequent plutocratic drift (Deaton 2013). An authoritative study has estimated that, in a technologically advanced economy open to world trade like the US, an optimal tax rate on the highest incomes could reach $76 \%$ without inducing any relevant macroeconomic distortion (Diamond and Saez, 2011).

At the same time, the tax system should be structured in such a way as to prevent the erosion of the tax base, especially by large multinational corporations; otherwise, the net effect induced by the simple increase in tax rates would be drastically reduced by capital flight. In United States, the transfer of profits to tax havens costs annually, to the federal government, about 200 billion dollars in lost revenue (Mayer-Schönberger and Ramge, 2018).

The problem of capital flight, induced by high taxation, could be marginalised if similar fiscal policies were adopted in a coordinated way by advanced countries, restoring collaterally pervasive controls on capital movements, as part of a controlled de-globalisation (Rodrik, 2015). The controlled reduction, through a multilateral approach, of the current level of openness of the global economy, would create a barrier to capital flight, and would allow an increase in the level of taxation.

With the global movement capacity of capital reduced, tax systems could again be based on rigid criteria of progressivity, and taxation shifted from labour to capital, from small and medium-sized enterprises to large corporations, and from medium to high incomes. With the extra revenue thus obtained, governments would have the necessary resources both to launch compensatory measures, designed to limit the effects of the technological revolution in 
progress. Thus, compensatory policies should be formulated considering the indications of the theory of endogenous growth regarding the roles played by human capital, innovation, and infrastructure in long-term growth.

Among other things, a higher tax burden could also have the effect of slowing down the ongoing technological restructuring itself, or could be used as a lever to condition it by varying the distribution of the tax burden, and by taxing the innovations that most directly replace human labour. For example, the European Parliament recently discussed the possibility of introducing a tax on robots (Russo, 2019 b). Such measures would have the effect of changing the matrixes of companies' convenience.

The State obviously cannot determine in a deterministic way the trajectory followed by technological evolution, but it can certainly modify the speed of the great restructuring underway. As Polanyi (1944) suggests, the role of government is precisely to alter the speed of change, to avoid it inducing disruptive effects on the social structure. By slowing down the speed of technological restructuring, the displacement effect on the workforce would be more controllable, involving lower volumes of work replaced by automation and robotization. This would also make it easier to define active policies for the labour market and the preparation of compensatory measures for the workers most affected by technological crowding-out.

In addition, the introduction of the Tobin tax could also limit speculation and, at the same time, drain resources to face future economic crises. To reduce the current level of financialization, a return to stricter antitrust regulation could be useful, by dismembering too-big-to-fail banking and financial groups. These financial groups represent a serious systemic threat to capitalism that cannot be ignored by governments. Similar measures should also be examined against hightech giants to support the return to more competitive and dynamic markets' configurations, without relevant barriers to entry. All these interventions, obviously, presuppose a reduction in capital mobility.

The strongest incentive to move quickly in this direction is represented by the fact that inequality is wearing down the democratic circuits of advanced countries and their internal cohesion. Capitalism needs a profound reform, which places growth on new foundations, in a framework of high social cohesion and democratic stability. It is necessary to circumscribe the level of deep integration achieved by current economies, to restore the redistributive action in democracies and to safeguard welfare state systems, in order to face the effects of the gigantic technological restructuring underway. Globalisation, financialization, and technological change are inextricably interconnected in cognitive capitalism, and therefore require a unitary policy action to be adequately addressed by governments.

\section{REFERENCES}

Acemoglu, D. and Robinson, J.A. (2012), Why Nations Fail, Profile Books, London, UK.

Baldwin, R. (2019), The Globotics Upheaval: Globalisation, Robotics and the Future of Work, W\&N, London, UK.

Brynjolfsson, E. and Mcaffe, A. (2017), Machine, Platform, Crowd: Harnessing Our Digital Future, W.W. Norton \& Co Inc, New York, USA.

Crouch, C. (2009), "Privatised Keynesianism. An unacknowledged policy regime, in British", Journal of Politics and International Relations, 11, pp. 382-399.

Crouch, C. (2011), The strange non-death of neoliberalism, Polity Press, Cambridge, UK.

Crouch, C. (2013), Making capitalism fit for society, Polity Press, Cambridge, UK. 
Deaton, A. (2013), The great escape. Health, wealth, and the origins of inequality, Princeton University Press, Princeton, USA.

Diamond, P. and Saez, E. (2011), "The case for a progressive tax: from basic research to policy recommendations", Journal of Economic Perspectives, 25, 4, pp. 165-190.

Dìez, F.J., Leigh, D. and Tambunlertchai S. (2018), "Global market power and its macroeconomic implications", International Monetary Fund Working Papers.

Gallino, L. (2011), Finanzcapitalismo. La civiltà del denaro in crisi, Einaudi, Torino.

Hacker, J.S. and Pierson, P. (2010), "Winner-take-all politics: public policy, political organization, and the Precipitous Rise of Top Incomes in the United States", Politics \& Society, 38, 2, pp. 152-204.

Lerner, J. (2009), Boulevard of broken dreams: why public efforts to boost entrepreneurship and venture capital have failed and what to do about it, Princeton University Press, Princeton.

Marx, K. (2011), "Per la critica all'economia politica", Andolfi, F. (Ed.), Marx. Le opere che hanno cambiato il mondo", Roma, Newton Compton Editori, pp. 546-662.

Marx, I., Nolan, B. and Livera, J. (2014), The welfare state and anti-poverty policy in rich countries, Institute for the Study of Labor, Discussion paper n. 8154.

Mason, P. (2015), Postcapitalism: a guide to our future, Penguin Books, London, UK.

Mayer-Schönberger, V. and Ramge, T. (2018), Reinventing capitalism in the age of big data, Basic Books, New York, USA.

Mazzucato, M. (2014), Lo Stato innovatore, Laterza, Bari (The entrepreneurial state, debunking public vs. private sector myths, Anthem Press, 2013).

Oecd (2011), Divided we stand: why inequality keeps rising, OECD Publishing, Paris, FRA.

Olson, M. (1982), Rise and decline of nations: economic growth, stagflation and social rigidities, Yale University Press, New Haven, USA.

Pérez, C. (2002), Technological revolutions and finance capital: the dynamics of bubbles and golden ages, Elgar, Cheltenham, UK.

Piketty, T. (2020), Capital and Ideology, Harvard University Press, Cambridge, Massachusetts, USA.

Piketty, T., Saez, E. and Stantcheva, S. (2011), Optimal taxation of top labor incomes: a tale of three elasticities, National Bureau of Economic Research, Working Paper n. 17616.

Polanyi, K. (1944), The great transformation, Beacon, New York, USA.

Rodrik, D. (2015), The globalization paradox. Democracy and the future of the world economy, W. W. Norton \& Company, New York-London.

Russo, A. (2017), Stato e mercato. Storia del pensiero, Utet Università, Torino.

Russo, A. (2019a), "Forze produttive, concentrazione del capitale e mutamento del capitalismo", Quaderni di Sociologia, 79, pp. 73-101.

Russo, A. (2019b), Political economy del capitalismo. Progresso tecnologico, potere politico e mutamento della società industriale, McGrew-hill, Milano. 
Russo, A. (2020), "International economic integration and social inequalities in modern capitalism", Fortunato, V. (Ed.), Old and new inequalities in a globalised world, L'Harmattan, Paris, pp. 151-176.

Schumpeter, J. A. (1943), Capitalism, socialism, and democracy, Allen \& Unwin, London, UK. Stiglitz, J.E. (2002), Globalization and its discontents, Penguin, London, UK.

Stiglitz, J.E. (2016), Rewriting the rules of the American economy, W. W. Norton \& Company, New York, USA.

Streeck, W. (2013), Tempo guadagnato. La crisi rinviata del capitalismo democratico, Feltrinelli, Milano (Die vertagte krise des demokratischen kapitalismus, Suhrkamp Verlag, Berlin, 2013). (https://www.wcsaglobal.org/ethics-policy/). 